\title{
Citizenship and Property Rights: A New Look at Social Contract Theory
}

\section{Elisabeth Ellis Texas A\&M University}

\begin{abstract}
Social contract thought has always contained multiple and mutually conflicting lines of argument; the minimalist contractarianism so influential today represents the weaker of two main constellations of claims. I make the case for a Kantian contract theory that emphasizes the bedrock principle of consent of the governed instead of the mere heuristic device of the exit from the state of nature. Such a shift in emphasis resolves two classic difficulties: traditional contract theory's ahistorical presumption of a pre-political settlement, and its impossibly high demands on citizens seeking to practice self-rule. Kant's solutions to these problems of property rights and citizenship are found in his political works, rather than the ethical works through which Kant's political theory is usually interpreted.
\end{abstract}

 he language of social contract permeates both politics and political science. Thomas Friedman complains in the New York Times about some countries' lack of social contract legitimacy, employing the historically dominant sense of a voluntary contract among citizens to form a government (Friedman 2005); opinion page writers complain that proposed social security reform "breaks the social contract" between government and senior citizens, using a slightly less traditional sense of the term. ${ }^{1}$ Commenting on a brawl at a basketball game between the Indiana Pacers and the Detroit Pistons, the commissioner of the National Basketball Association, David Stern, complains that the "social contract" between players and fans has been broken (Lyon 2004).

Political scientists, too, rely on concepts from social contract theory, including "consent," "interest," and the "state of nature." In Political Science: The State of the Discipline (Katznelson and Milner 2002a), representatives of a wide variety of subdisciplines cite such contractarian concepts as the consent of the governed (Katznelson and Milner 2002b), property rights and the state (Levi 2002), and the anarchic state of nature (Powell 2002). Philosophers and economists continue to treat contractarianism as a live project, and political scientists interested in game theory sometimes take their grounding assumptions from this body of work (Morris and Oppenheimer 2004). The social contract forms the central idea of John Rawls's 1971 A Theory of Justice, a book widely credited with the revival of academic political philosophy in the United States.

Yet none of these contributors, popular or scholarly, has been able to provide a satisfactory response to two persistent complaints about social contract theory's application to imperfect political conditions. First, how can political authority derive from contract theory's frankly hypothetical, ahistorical description of pre-political human agents agreeing to leave the state of nature and submit to government? Second, how can authoritative consent be granted by realworld citizens subject to conditions ranging from imperfect to utterly disabling? Sugden, in the introduction to a collection of essays celebrating David Gauthier's minimalist contractarianism, glosses the two questions as "baseline" and "reciprocity" problems, adding that their persistence makes "even the most committed contractarians uneasy" (Sugden 1993). ${ }^{2}$ Frustration with contract theory's failure to answer such questions has led some theorists to

\footnotetext{
${ }^{1}$ The Oxford English Dictionary (1989) lists both senses, but places priority on the sense of "mutual agreement which, according to Rousseau's Contrat social (1762), forms the basis of human society."

${ }^{2}$ Sugden does not characterize Gauthier's contractarianism as "minimalist," as I do, but as "strong." For Sugden, "weak" contractarians such as Locke, Rawls, and Harsanyi "inject" impartial starting conditions into their theories, biasing them in favor of morality. Sugden's "strong" contractarians, including Gauthier and Hobbes, may end up claiming that rationality favors morality, but they begin only with the principles of rational choice (Sugden 1990).
}

The Journal of Politics, Vol. 68, No. 3, August 2006, pp. 544-555 
dismiss it as "fiction," or to attempt to go "beyond the social contract" with an alternative approach (Nussbaum 2004; Shapiro 2003). However, I argue that these criticisms reach only the minimalist type of social contract theory, not the provisional contractarianism advocated by Kant and his successors. ${ }^{3}$

Both normative and empirical scholars of politics have mistakenly identified social contract theory with minimalist contractarianism. Students of democratic politics often presume that minimalist values such as a pre-political right to property and minimalist assumptions about independent citizen capacity represent uncontroversial contractarian principles. Social and political theorists, making the same presumption about the status of the minimalist view, argue against its uncritical acceptance. Students of democratic politics tend to presume contractarian values because they are widely held and popular in practice; critics of contractarian thought argue that these same values are ahistorical and incoherent. Paradoxically, both sides are right. The contractarian values undergirding present-day democracy are indeed broadly accepted, but they are not the values defended by contemporary minimalist contractarians. Political theorists have rightly criticized minimalist views of property and citizen capacity "as just one more installment in a tradition inherited from Locke of mystifying anachronism" (Braybrooke 1987, 750). In identifying contract theory generally with the minimalist version of it, scholars of politics mistakenly focus on the conditions of consent, rather than the principle itself. Moreover, since the conditions of genuine consent change over time and space, the values commonly associated with contractarianism in the literature have grown increasingly irrelevant to arguments about democratic governance today (see Pierson 2004).

By adhering to a seventeenth-century model of civil society, in which individuals independently endowed with property and with the capacity to exercise political judgment contract together to found the state, minimalist social contract theory fails to realize the fundamental contractarian value that legitimate rule is by the consent of the governed. ${ }^{4}$ As Kant rec-

${ }^{3}$ Provisionalism has recently been given a thoughtful treatment in Gutmann and Thompson's collection of essays on deliberative democracy (2004). Though Rawls constructs a Kantian contractarianism, he does not advocate provisional right; nor is Rawls much influenced by Kant's political, as opposed to his ethical, ideas. See Shaw (2005).

${ }^{4}$ In a similar vein, Przeworski calls for putting "the consensualist theory of democracy where it belongs-in the Museum of Eighteenth-century Thought" (Przeworski 1999, 44). Przeworski's minimalism is very different from Gauthier's minimalism; in fact, ognizes in his work on provisional right, vindicating such a principle in the dynamic political world requires an ever-changing set of institutions aimed at adjusting political reality in the direction of its ideals. It does not make sense, then, to identify contractarianism proper with certain seventeenth-century views on the necessary preconditions of genuine consent. The social contract idea remains the basis of contemporary democratic politics; particular theories of property rights and citizen capacity have continuing relevance only insofar as they promote contractarian freedom under prevailing social circumstances.

Despite its continuing association among academics with an outmoded and particular set of conditions, the discourse of social contract has not lost its popular allure. Kant understood that the underlying logic of social contract as the exercise of collective selfrule, as the real-world approximation of the moral ideal of freedom, holds far more promise than the mere heuristic story of the exit from the state of nature. Ordinary language mirrors this Kantian insight, emphasizing the voluntary choices of human agents; when Stern used the term "social contract" in criticizing the basketball brawlers, "he meant the unspoken understanding that there were certain things one side didn't do and certain places the other side didn't go" (Lyon 2004, E1).

I shall argue that Kant's revisionist contractarianism improves upon conventional minimalist social contract theory by giving a dynamic account of the property-rights and citizen-capacity conditions of consent while retaining contract theory's attractive commitments to autonomy, equality, and political freedom. Kant's account of the provisional right to property addresses the first traditional complaint about contract theory's unempirical commitment to an imaginary "baseline" status quo. Kant's account of active citizenship, though riddled with its own problems, resolves the second traditional complaint about "reciprocal" citizen capacity. More generally, Kant's approach to thinking about legitimate institutions as a series of provisional efforts to improve imperfect political reality while maintaining the conditions of the possibility of progress provides a model for politics that is both more realistic and closer to contractarian essential principles than the minimalist view.

Przeworski's minimalist democratic theory exemplifies an appropriate use of contractarian thought in political science, as he does not confuse historically particular enabling conditions with democracy itself. For the purposes of this article, "minimalism" refers to contractarian thought that would limit realization of the principle of government by consent by means of the conditions of that consent, including not only Gauthier, but also Buchanan and Tullock (1962) and Nozick (1974). 


\section{The Provisional Response to Minimalist Contractarianism}

A provisional understanding of contract theory demonstrates that minimalist bias toward a "baseline" status quo and unrealistic expectations for "reciprocal" citizenship are not essential elements of the contractarian argument. Kantian provisionalism denies what Gauthier asserts, that pre-political circumstances take normative priority over political will. The logic of contract theory, with its central ideal that legitimate government rests on the consent of the governed, does not entail any single, conclusive system of property rights. Moreover, the changing empirical context of politics implies changing pragmatic conditions for the satisfaction of its ideals of citizenship. Seventeenthcentury English landholders brought very different capabilities to the political table than twenty-first century wage-laborers do, and a minimalist contractarianism vindicating the autonomy of the former may end up denying the freedom of the latter. Sophisticated contract theory has always been hypothetical rather than historical, asking about the legitimation of current government rather than justifying it according to any real agreement among distant ancestors. ${ }^{5}$ But some contexts require more hypothetical distance than others. In the context of the English civil wars, talk of choosing to suspend the exercise of some natural rights in return for common security was at least plausible; the choice between life with or without a state was also relatively close to the reality of periods of lawlessness and frequent, violent, changes of regime. In the rich democracies these days, the hypothetical choice to submit to state sovereignty rather than remain a free agent with full exercise of one's natural rights seems far less plausible. Wealth and other resources, even developed natural talents, that a supposed free agent might bring to the contractarian bargaining table all depend in one way or another on the stability and environment guaranteed by the state.

Must a Kantian contractarian conclude that since all social goods are made possible by the order guaranteed by the state, collective priorities as assigned by the sovereign trump all other concerns? Certainly

\footnotetext{
${ }^{5}$ David Hume famously lampoons the idea of an historical social contract in his 1748 essay, "Of the Original Contract": "The face of the earth is continually changing, by the encrease of small kingdoms into great empires, by the dissolution of great empires into smaller kingdoms, by the planting of colonies, by the migration of tribes. Is there anything discoverable in all these events, but force and violence?" (Hume 1994, 190).
}

not. ${ }^{6}$ Instead of reasoning from the hypothetical example of the transition from the state of nature, which has never been more than a highly useful mode of illustration for the logic of contractarianism, we ought to reason from the social contract's most basic commitment: legitimate rule is by consent. Rule by consent is a provisional principle, and the conditions of its even partial satisfaction vary according to the political context. In present-day rich democracies, the conditions of citizen self-rule are more demanding than ever. Today's minimalist contractarians recognize this fact, but they draw the wrong conclusion. Gauthier argues, for example, that only relatively enabled citizens capable of exchanging benefits with their fellows (and this criterion excludes the severely disabled, among others) ought to be parties to the social contract that legitimates government $(1986,17){ }^{.}$But modern citizens do not assemble a package of enabling conditions under pre-political circumstances. Instead, the development of citizen capacity occurs in a dynamic institutional setting in which state and nonstate actors respond to broad sets of incentives set by the marketplace, government regulation, and historical conditions. The distribution of citizen capacities in any given context is the product of political negotiations as well as social and economic conditions, not to mention countless decisions made by individuals more or less interested in self-development (Burns, Schlozman, and Verba 2001; Fraser 1994; Orloff 1993; Putnam 2000; Skocpol 2003). Since citizen capacity is an essential condition of contractarian consent, contractarian theory cannot simply presume that agents bring such capabilities to the political arena under all possible social circumstances.

Recognizing that the imperatives of the state-ofnature hypothesis conflict with those of the demand

\footnotetext{
${ }^{6}$ This is the choice to which Rawls refers near the end of his Lectures on the History of Moral Philosophy, where he argues against Hegel that one need not choose between the priority of either "single individuals as atoms" or "the state as a concrete whole." Instead, Rawls points to Kant's contractarian theory, of which he says that "it is different from starting with single individuals as atoms independent from all social ties and then building up from them as a basis. And it does not use the idea of the state as spiritual substance and individuals as mere accidents of its substantiality; the state is the arena in which individuals can pursue their ends according to principles each can see are reasonable and fair" (2000, 364-65). See also Morris and Oppenheimer $(2004,7)$.

${ }^{7}$ The exclusive consequences of this view of contractualism are agreed upon by minimalist contractualists and their many critics; by contrast, I hold that exclusivity is one of two possible solutions to the problem of autonomous citizen consent, and the less attractive of the two. Gauthier even suggests that social contract theory as an ideology is undermined by the inclusion of previously excluded groups (1977, 160-63).
} 
for government by consent, Gauthier chooses the former: "A nonarbitrary society must improve on the natural outcome for everyone" $(1977,141)$. Gauthier's declaration of principle emphasizes the minimalist presumption in favor of the status quo in property rights, as well as a counterfactual baseline state of nature. But note that despite his explicit decision to accord priority to property rights, the more fundamental value presumed in this sentence is that of "nonarbitrary society." Gauthier recognizes that the human aspiration to transcend arbitrariness is what I would call a provisional goal; of course every social condition contains arbitrary, unjust, morally irrelevant elements. However, like all social contract theorists, Gauthier is ultimately committed to an ideal of human freedom. Perfect freedom is impossible, but freedom as an ideal is not only possible but necessary for Gauthier and for contractarian thought of all stripes. Gauthier rightly prioritizes freedom, but wrongly identifies it with the state-of-nature hypothesis rather than the more fundamental ideal of government by consent.

For Gauthier, a free citizen is someone of whom one can say that it is in his rational interest to be a member of the state that has authority over him (this is the exit-from-the-state-of-nature test, which I call the "minimalist test"). Gauthier knows that real citizens are not offered such a choice, but he argues that legitimate government must be one that ideal citizens would freely choose to join. He uses a rich definition of freedom that includes a Kantian dimension of moral autonomy, explicitly rejecting what he calls "Hobbesian or anarchistic interaction, in which each may pursue his greatest benefit without concern for the effects of this pursuit on others" $(1986,258)$. Gauthier's choice of the minimalist, join-it-or-leave-it test, however, cannot do justice to his notion of freedom in any but the simplest of counterfactual contexts. In fact, the demands of the kind of political freedom that would make government by consent at least a provisional reality require modern contractarians to reject the conclusions that minimalists draw from the stateof-nature hypothesis, including especially their account of property rights.

\section{Provisional Respect for Property}

Kant's politics should not be derived from his ethics. Anyone reading Kant's political essays even casually will notice that they are filled with fascinating arguments and hypotheses about the practice of politics, even though most of the secondary literature on Kant limits itself to formalistic abstractions illustrated by ill-chosen examples from ethical treatises like the Groundwork of the Metaphysics of Morals. ${ }^{8}$ In his political essays, Kant gives us arguments about live political questions: how to trick the monarch into making himself obsolete; why permanent rule-giving of any kind is illegitimate; why freedom of expression matters; why gradualism is to be preferred to revolution; why the intelligensia should get special rights(!); how regime change occurs; what institutions promote international peace; how to treat foreigners rightly, and so forth. True, Kant takes the conclusions of his ethical work for granted in his political theorizing; he treats corollaries of the categorical imperative as conclusive principles of political right. However, Kant in his political theory is concerned not simply to lay out another ideal system of politics, however well or illgrounded, but to understand the relationships among pragmatic politics, public applications of moral judgment to political practice, and the processes of political change. ${ }^{9}$ Kant does construct an ideal republican political system, but his main theoretical innovation lies elsewhere, in his account of provisional right. Provisional right, as I explain below, emphatically does not mean a temporary free pass for wrongdoing in the name of pragmatic political ends. ${ }^{10}$ Instead, it is something much subtler and more interesting: provisional right is a response to the inevitable uncertainties that arise from the hybrid, half-ideal, half-empirical world of politics. Thus provisionalism allows Kant to analyze, even to celebrate, the moral element in political life without retreating to the usual castle-in-theair built by conclusive theory in spite of reality.

It is one thing, however, to posit that morality matters for politics and quite another to argue that a particular set of moral principles is conclusively authoritative. ${ }^{11}$ Political theorists who place Kant's

${ }^{8}$ Some recent exceptions include: Shaw (2005), LaVaque-Manty
(2002), Muthu (2000), Flikschuh (2000), Cavallar (1999), and Laursen (1992).

${ }^{9}$ In this regard, see Pogge's interesting critique of Rawls's interpretation of Kant. Pogge argues that Kant's politics can accommodate Kantian morality as a comprehensive doctrine, but need not exclude other comprehensive doctrines. According to Pogge's reading, "Kant emerges as the freestanding liberal par excellence" (2002, 149; see also Ellis 2005).

${ }^{10}$ It would also be a misunderstanding to confuse provisionality with relativism. Research in the history of political thought and observation of contemporary political behavior reveal the nearubiquity of conclusivist moral argument in political life. As Kant famously puts it, "true politics can ... not take a step without having already paid homage to morals" (1996, 8:380).

${ }^{11}$ Provisional arguments take the form of hypothetical imperatives: if we are committed to $\mathrm{x}$, then $\mathrm{y}$ and such follows in $\mathrm{z}$ and such a 
ethics at the center of his politics make a mistake: they take the content of Kant's moral system to be critical, when what matters for politics is the fact of human morality itself. Since human beings are capable of agency, any politics that ignores the role of judgments about the right made by political agents will be inaccurate: political ideals have concrete political effects. Kant argues that a single moral law governs all human agents, but even so, as a clear-eyed interpreter of the political world, he knows that the sources of political authority in really existing societies vary. Thus he argues for provisional rather than conclusive political right: right that applies in the absence of universally authoritative political judgment. A general formulation for provisional right in specifically Kantian language is: "always leave open the possibility of entering into a rightful condition" (6:347).$^{12}$ Kant identifies the distinction between provisional and conclusive right and applies it to various political topics, such as the determination of which violations of international right are immediate threats to the possibility of world peace, and which might be provisionally tolerated (8:343-49). Even as Kant presumes in his ethics that he has identified a universally authoritative set of moral rules, in his politics, he recognizes both human agency and plurality. For example, Kant argues in "What is Enlightenment?" that any group of authorities attempting to set down conclusive moral rules for posterity necessarily violates future generations' human agency (8:39).

Obviously, there are plenty of tensions in Kant's work. The political theory Kant and others derive straight from his ethical first principles is a nice, moderate republican social contract view of some historical importance (Beiser 1987, 1992). Even Patrick Riley, whose seminal work of the 1970s and 1980s renewed interest in Kant's political thought, can generate only moderate enthusiasm for the ideal theory, calling it "the most adequate of the social contract theories" (Riley 1982, 125). It was not news, even in Kant's time, that a republican system of government ought to respect basic freedoms, ought to separate the executive and legislative authorities, ought to guarantee

context. Arguments with conclusivist ambitions—based on divine right, the ideal speech situation, rational choice, biological imperatives, or the greatest happiness of the greatest number, to take a few examples - aim for universal application.

${ }^{12}$ References to Kant's works are designated by the volume and page number in the standard Prussian Academy edition. In English, the Cambridge University Press editions of Kant's works include the standard pagination. The translations given here are from Gregor's excellent volume in the Cambridge edition (Kant 1996). equal protection under the law. ${ }^{13}$ These views comprise a static, rather than a dynamic, political theory. Kant himself plays down the value of this type of intellectual labor, saying in The Conflict of the Faculties that building ideal republics is ultimately irresponsible (7:92).

Instead, strangely ignored by nearly everyone but Habermas (whose Structural Transformation of the Public Sphere ([1962] 1989) contains a brief but brilliant exposition of Kant's theory of publicity), Kant struggles in a series of efforts to come up with a dynamic theory of politics appropriate to limited rational beings interacting with each other. His formal contract theory is set out in the Rechtslehre, the first half of the Metaphysics of Morals, and begins with an account of property rights that starts out conventional and becomes a radical departure from the contractarian tradition. With regard to property rights, Kant's provisional contractarianism turns conventional wisdom on its head. Kant does not accord priority to the status quo in property holding, but neither does he posit a radical break between the state of nature and the civil state. Instead, given the clay feet of every existing state, he argues for provisional recognition of property rights. Kant avoids the traps of according absolute priority either to a "baseline" state of nature or to the state (more particularly: either to individual property rights or to redistribution according to some general interest (6:323-24)).

Kant developed the concept of provisional right over a series of works and first made sustained use of it in Perpetual Peace, two years before setting out the social contract theory of the Rechtslehre. For Kant, the concept of provisional right applies to institutions that imperfectly mirror their own normative principles; since all existing political institutions do this, pragmatic politics must follow a rule of provisional rather than conclusive right. In his Rechtslehre, Kant claims that the right that applies in real-world civil societies must be "provisional" (provisorisch) rather than "conclusive" (peremptorisch): provisional right holds in anticipation of and preparation for the more perfect state of conclusive right (6:257). Kant uses an early version of this distinction in his famous essay on international politics, Perpetual Peace, where he argues that even though many types of state action are in

\footnotetext{
${ }^{13}$ Kant's views on the importance of freedom of the pen were radical, original, and even "subversive" in their historical context, as Laursen $(1986,1992)$ has established. However, it is Kant's hypotheses about the role of press freedom as a social agent of change that distinguish his theory from more general arguments for freedom of expression, and these hypotheses form an essential part of his dynamic theory of provisional right.
} 
blatant violation of universal moral norms, only some of those violations must cease immediately. States that make peace treaties while secretly preparing for war, that forcibly interfere in the domestic affairs of other states, and that use methods that poison the possibility of future trust, such as assassination, not only violate moral norms, but by their conduct prevent the possibility of future peaceful relations; these types of violation must not be tolerated. On the other hand, international actors which violate moral norms by treating the state as personal patrimony, maintaining standing armies, or using national debt to promote military adventure ought to cease such practices, but they may do so gradually, since these three violations do not prevent the possibility of progress as such $(8: 343-47) .{ }^{14}$ For Kant, the primary rule of provisional right, which is the rule that applies to all societies between the state of nature and the ideal republic, is to promote the possibility of progress. ${ }^{15}$

Similarly, in his discussion of property in the section on private right in the Rechtslehre, Kant distinguishes between provisional and conclusive rights, and in the process distinguishes himself from his predecessors in social contract theory. "Conclusive acquisition takes place only in the civil condition," whereas provisional acquisition takes place "under the idea" of civil right (6:264). Provisional possession for Kant is possession in the absence of a rightful civil condition. All existing societies fall into this category: their people are not in a state of nature, but they do not enjoy a just legal system as sketched in Kant's image of the ideal republic. Thus property rights in these intermediate societies, which include all real ones, are always provisional.

Private right, for Kant, is "the sum of laws that do not need to be promulgated." That is, private right exists without actual legislation; a people need not even be constituted as such before private right comes into play. By this, however, Kant does not mean to agree with minimalist contract theorists that private right prevails in a state of nature. The contrary is the case: though it comes into force without explicit leg-

\footnotetext{
${ }^{14}$ On Kantian liberalism and the democratic peace thesis, see Danilovic and Clare (2005), who make a convincing case that empirical work on the democratic peace ought to incorporate specifically liberal variables rather than relatively blunt measures of democratic status.

${ }^{15}$ Note that this pragmatic norm is at odds with the received wisdom on Kant's politics, which distills a rigoristic set of political principles out of his ethical works. Readers of Kant's political works will enjoy a very different sort of argument, one that is context-sensitive and attentive to modern concerns like the difficulty of constructing a predictive science of politics.
}

islation on the part of any body, private right by its very nature implies the existence of a state of civil order $(6: 210 ; 6: 256-57)$. Flikschuh, in a brilliant analysis of a much-misunderstood passage, explains the differences between Locke and Kant on property and the state of nature: "In fact, Kant faults the Lockean view on two counts: first, in thinking that property rights denote a direct relation between subject and object; and, second, in assuming that a unilateral act of empirical acquisition (such as the act of investing one's labour in the object) can establish a rightful claim ..." $(2000,118)$. Kant insists that there can be no rights to things as such; rights for Kant are one kind of relation among persons: "Speaking strictly and literally, there is ... no (direct) right to a thing" (6:261). All such relations, if they are to honor the only natural right which is to autonomy (6:237), must be based not on a unilateral but a general will (and unilateral here of course includes any number of wills less than the whole); by their very existence property rights presume the republican state, at least provisionally.

While for Locke property rights are established as soon as one's labor has been mixed with natural resources, for Kant, the necessity of property's possibility implies a condition in which mutual obligations to respect each other's autonomy prevails (Locke [1689] 2003; Flikschuh 2000). These rights of persons against each other are one practical application of Kant's universal principle of right: "Any action is right if it can coexist with everyone's freedom in accordance with a universal law, or if on its maxim the freedom of choice of each can coexist with everyone's freedom in accordance with a universal law" (6:230). Kant claims to have deduced the possibility of property rights from this principle conclusively, a claim which has not withstood the test of time (Rosen 1993). However, what matters for my purposes here is that Kantian property rights are, first, based on relations among persons rather than between persons and things, and, second, divided between provisional and conclusive rights.

For Kant, the only natural right is the right to autonomy (6:237). Why, then, would he begin his account of political obligation with the contractarian story of the pre-political establishment of at least provisional rights to private property? The answer must lie in the physical conditions of pragmatic autonomy, though of course an argument from abstract principle such as that given in the main text of the Rechtslehre cannot begin from such "anthropological" premises. As Wolff (1998) has argued regarding this passage, human beings must appropriate objects from 
nature in order to sustain themselves. If, the argument goes, autonomy is to be practicable, some independent access to our means of sustenance is necessary for us. Some form of private property, then, must be possible for potentially autonomous agents.

Note that in this case, private property is justified as a condition of possible human agency. Minimalist contractarians, by contrast, take private property as a part of what contracting agents bring to the pre-political bargaining table (Gauthier 1986, 1993). Property on this minimalist account is a constitutive element of personhood. Not so for Kant. Even though elsewhere Kant makes a robust pragmatic case for respecting property rights through political transitions, he does not make the case for any fundamental right to property. Kant's direct argument on the subject, the failed deduction, only deduces the necessity of the possibility of property rights. Instead, for Kant property rights ought to be respected provisionally because such respect serves other, more fundamental interests, including especially an interest in political stability.

In the minimalist contractarian story, independent rational agents form a society and authorize a government in order to protect their lives and property. Government by consent in this account follows from the conditions of the exit from the state of nature (what Gauthier calls departures from the natural outcome). Kant's contract theory reverses these values. Agents must enter into mutually enforceable and mutually agreed upon contracts in order to vindicate their natural right of autonomy, that is, of being free from determination by another's choice. No agreement, even one to respect property, can be prior to this fundamental agreement for Kant. However, since even outside established society and rule of law, human beings will need to appropriate objects in order to survive, Kant grants provisionally rightful status to property held in the absence of the just state. Thus for Kant, the conditions under which agents would rationally exchange their natural freedom for the security of government are relatively unimportant; what matters are the conditions under which government by consent is at least provisionally possible (and these conditions may well include some form of property rights). Provisional property rights thus follow from Kant's natural right of autonomy and its principle that legitimate government is by consent.

Kant introduces the problem of property rights thus: "It is possible to have something external as one's own only in a rightful condition, under an authority giving laws publicly, that is, in a civil condition" (6:255). Kant has already argued that ownership of property must be possible; now he sets out the dis- tinction between natural and positive rights, arguing that the only natural right is to one's freedom (in the sense of autonomy outlined earlier: freedom from others making choices for one) (6:237-38). Kant argues that for property and personal autonomy to coexist, no one should have to acknowledge anyone else's property without guarantees that his own property will be acknowledged in exchange. To do so would be to violate the only natural right, since the one unilaterally acknowledging others' property will have to rely on the others' presumed good will for the security of his own property (and will thus enter a condition of heteronomy) (6:255-56; 6:307). Since for Kant, only a "collective general (common) and powerful will" can provide the guarantees necessary for this property rights regime to exist, a "unilateral will" (any will less than general) cannot command anyone's obedience without infringing on autonomy. Potentially interacting persons, then, must submit themselves to a common source of authority for the validation of their reciprocal natural right $(6: 256)$.

Unlike minimalist contractarians, Kant's contract theory holds that property rights do not precede the advent of the state. He admits the necessary possibility of private property generally, but argues that their assertion under heteronomous conditions amounts to an illegitimate, unilateral fiat. Rather than denying the possibility of just property holding outside (an unreachable) state of republican perfection, however, Kant introduces the concept of provisionality:

In a state of nature something external can actually be mine or yours but only provisionally.... Possession in anticipation of and preparation for the civil condition, which can be based only on a law of common will, possession which therefore accords with the possibility of such a condition, is provisionally rightful possession, whereas possession found in an actual civil condition would be conclusive possession (6:256-57).

For Kant, an actual civil condition requires the general will to be realized; in the Rechtslehre, "Theory and Practice," and elsewhere, Kant sketches the demanding conditions required of any polity wishing to conform to ideal republican standards. All existing states fall short of these ideals, though Kant argues that by their very claims to provide order they implicitly recognize the standards' normative authority. Since all existing states fall between pre-political chaos and ideal republican governance, provisional right is the rule that applies to them $(6: 264)$.

Thus Kant's contractarianism places first priority on the demand for autonomous consent, and only grants secondary status to private property as a condition of civil society's acceptance of government. 
Kant does call for the status quo in property rights to be respected during political transition, but not in the name of any original legitimacy. Instead, he refers to a general societal interest in reformist rather than revolutionary transitions. ${ }^{16}$ Kant's argument for respecting the status quo in private property thus rests on the empirical hypothesis that the moral interest at stake (everyone's interest in living under some stable order, even one only on the way to justice) would be best served by a policy of provisional respect. The claim is in principle falsifiable and subject to different answers at different times and places. ${ }^{17}$ A Kantian contractarianism takes no conclusive stand on property rights; instead, property is accorded provisional respect as circumstances demand.

\section{Theory and Practice of Citizen Consent}

In the Rechtslehre, Kant famously and wrongly sets out a distinction between active and passive citizens, consigning a large portion of society to mere civil rights while limiting positive political participation to a minority. I am not interested in defending this position. What matters about it for my purposes, however, is that Kant's awkward distinction reveals his awareness of a critical problem in making his version of contract theory coherent. As I have argued, Kantian contractarianism prioritizes the basic principle of government by consent over any set of presumed natural rights to property carried over from prepolitical existence. Such a theory places great demands on citizens as autonomous self-legislators. Making good on the ideal of autonomous consent is no easy task. Minimalist contract theorists such as Gauthier seek to limit reciprocal political obligation to those "enabled" to exchange fruitfully with their fellows (this follows

\footnotetext{
${ }^{16}$ In a significant departure from conventional contract theory, Kant denies the legitimacy of violent revolution, arguing from the principle of provisional right to the effect that quick rather than gradual transitions actually undermine rather than promote the possibility of eventual good government. The problem of revocable contracts is a thorny one for contractarians, particularly for Hobbes, but Kant sets it aside almost too easily. That he can do so demonstrates that the language of the exit from the state of nature is less important to Kant than the principles underlying the social contract in the first place.

${ }^{17}$ In fact, there is no consistent lesson to be drawn from the political science literature on the wisdom of maintaining strict respect for property rights across political transitions. For an interesting take on the evidence from the Latin American cases, see Mason 1998.
}

from their emphasis on the conditions of a hypothetical exit from nature). Other students of politics have described citizenship as an ongoing series of battles for rights (Marshall 1964), or sought to limit democratic citizenship to those societies predisposed to it (Huntington 1996) or developed enough to handle it (Mill 1989). Kant, then, is certainly not alone in seeking to address the problem of the high demands of contractarian citizenship through exclusion. However, the democratic implications of his moral presumptions and the dynamic nature of his provisional theory of politics make it much harder for Kant than for other theorists coherently to maintain exclusion as his solution to this problem. As I shall demonstrate, the resulting tensions in Kant's writing on citizenship point in the direction of a Kantian contractarianism that rejects exclusion and thus more fully embraces its commitment to the bedrock principle of citizen consent.

At Rechtslehre (6:314-15), Kant makes his notorious distinction between active and passive citizenship, arguing that full citizens must be free, equal, and independent. In order to satisfy the criterion of independence, citizens must have what he calls civil personality. He illustrates his distinction with a series of contrasts between citizens able to support themselves and those who are somehow dependent on others for their livelihoods, including among others women, apprentices, domestic servants, and day laborers. This distinction has been widely and rightly criticized as illiberal and undemocratic. However, in order to understand how provisional contractarians address the problem of citizen capacity (what Sugden and other minimalists call the problem of "reciprocity"), we need to grasp the reasons motivating Kant's view.

Kant's distinction between active and passive citizenship occurs in the empirical remark that follows his description of the third key attribute of the citizen considered as legislator in an ideal republic: civil independence. ${ }^{18}$ Kant explains in the general argument preceding the remark that this civil independence of the citizen means "owing his existence and preservation to his own rights and powers as a member of the commonwealth, not to the choice of another among

\footnotetext{
${ }^{18}$ In his Rechtslehre, Kant distinguishes between general philosophical argument, which he puts in the main text, and particular empirical remarks, which he indents. Noting that the study of politics inevitably involves historical, empirical facts and their relation to commonly held moral principles, Kant concludes that a perfectly formal, example-free metaphysics of right would be impossible and necessarily incomplete; this is why he called his first section "metaphysical first principles of the Rechtslehre" instead of the more elegant "metaphysics of right."
} 
the people. From his independence follows his civil personality, his attribute of not needing to be represented by another where his rights are concerned" (6:314). Kant knows that he is outlining an ideal standard that can never be met in practice. Real citizens are enmeshed in webs of interdependent relationships, just as real states are begun when some one seizes supreme power and establishes order (6:372; see also 6:323). What matters is that citizens, considered as legislators, must be accorded the respect that would accompany such a feat of civil independence; they must be treated as if they are independent civil personalities. Perfect liberty, equality, and independence are not to be had even among self-legislating human beings. Nevertheless, their converse qualities of servitude, inequality, and dependence threaten the authority of the citizen-legislators. Rather than concluding that would-be free people must either undergo deep social and psychological transformation in preparation for self-rule, or accept tyranny as their lot, Kant makes an argument from provisional right. Promote the possibility of progress toward ideal citizen-legislators with the counterfactual presumption of their liberty, equality, and independence, Kant implies, and one will have powerful arguments to wield when servitude, inequality, and dependence threaten the legislators of the republic.

Now all this is very nice in theory, but in practice Kant actually followed this general, a priori passage with an empirical discussion of just which citizens might actually qualify as legitimate possessors of civil personality. He argues that "an apprentice... a domestic servant... a minor [in natural or even more, in civil minority]... all women, and, in general, anyone whose preservation in existence (his being fed and protected) depends not on his management of his own business but on arrangements made by another (except the state). All these people lack civil personality ..." (6:314). In perhaps his most telling example, Kant contrasts the Indian and the European styles of blacksmith work: the former carries his tools to his customers, and thus lacks, for Kant, independence, while the latter works in his shop and sells his goods on the market, and thus possesses, for Kant, the requisite quality. With the benefit of many years' hindsight, we are able to say to Kant that embeddedness in market rather than premodern personalistic economic relations is no guarantee of civil personality.

But what was Kant trying to achieve with his blatantly "anthropological" point about the social roots of civic standing? He argues that freedom, equality, and independence are the qualities that will lead to the best achievable political judgment on the part of human legislators. ${ }^{19}$ With his distinction among members of society and their qualifications for full civil personality, Kant is trying to establish authoritative political judgment by the only available means: the partial, limited human beings that he compares famously to "crooked timber." Critics of Kant who complain about his unrealistic expectations for abstraction and universalization on the part of ordinary reasoners should consider this part of Kant's political work. Here he seeks to approximate authoritative political judgment by excluding what he considers to be the social sources of corrupt judgment: servitude, inequality, and dependence.

Kant recognizes the demands of morality regarding citizenship, but does not believe that the institutions available are up to the task of providing even provisionally independent citizenship to all members of society. He admits that "the concept of a passive citizen seems to contradict the concept of a citizen as such" (6:314). However, Kant's commitment to providing a dynamic theory of politics in the provisional mode prevents him from simply condemning his unworthy contemporaries or from revising the strictures of the moral law in the direction of realism. Instead, Kant insists on the primacy of the moral law in generating political legitimacy, while imagining transitional institutions that would make the best socially possible approximation of the moral law's criteria while promoting the possibility of getting closer to those goals. With regard to citizenship qualifications, Kant tries to identify those among his contemporaries most likely to behave as if they enjoyed fully independent civil personality. Recall that Kant is writing from the northeastern hinterlands of eighteenth-century Prussia; when he compares Indian with European handworkers, he is encouraging his fellow citizens of Königsberg to identify with the European model, not describing an accomplished economic transition. Kant's views on the connection between civil personality and market rather than personalized economic relations were typical of enlightened thinking of his era. However, his case for the provisional exclusion of passive citizens from a role in legislation contains none of the usual arguments; he does not fear mob rule, essentialize second-class

\footnotetext{
${ }^{19}$ The distinction between active and passive citizenship is only one of several mutually incompatible arguments Kant attempts in his effort to establish the best possible political judgment among limited rational beings. Elsewhere in his writings, Kant argues variously for disinterested spectators or deliberative scholars to play this role $(7: 84 ; 7: 88-89$; see also $8: 41-42)$.
} 
status, or seek to empower a natural aristocracy. Kant's worry about participation by those in positions of dependence has to do instead with the institutional barriers against free, equal, and independent judgment faced by such people. Far ahead of his time, Kant recognizes the "private roots of public action" (Burns, Schlozmann, and Verba 2001). True, there are echoes here of the classical democratic conception of the demos as a collection of independent heads of household, with their status as tyrants in their domestic spheres guaranteeing independence in their public roles as citizen legislators. Kant is, as is often the case, right on the cusp of a modern conception of politics. Unlike either Rousseau or Jefferson, Kant did not expect a reordering of society to undergird the autonomy required of modern citizen legislators. This autonomy would have to remain an authoritative if unreachable ideal toward which citizens strive and by which they judge each other.

An advantage of Kant's provisionalism as opposed to Rousseauian and Jeffersonian radicalism is that in Kant's system, citizen self-rule does not presuppose, but proceeds concurrently with, progressive societal transformation. For pragmatic purposes, Kant could not imagine universal citizen self-rule applied to his society. The gap between the idea of autonomy and the reality of near-feudal economic and social relations was too wide. But rather than build a closed society of self-legislators on the foundation of permanent exclusion, and furthermore given that no really existing citizen meets the criteria for full civic personality in practice anyway, Kant suggests two means for approximating the ideal of universal civic autonomy. First, he requires genuine social mobility: "anyone can work his way up from this passive condition to an active one" (6:315). Second, he requires that citizen legislation be justified in the name of the interests of all, not just to those who are provisionally granted the exercise of a civil personality for which they only partly qualify: "whatever sort of positive laws the citizens might vote for, these laws must still not be contrary to the natural laws of freedom and of the equality of everyone in the people corresponding to this freedom" (6:315). Elsewhere in the Rechtslehre Kant argues that positive law must enact what the general will of the people could hypothetically approve. From a pragmatic point of view, having to justify political action in public according to a particular set of conditions limits the range of possible action available even to a would-be tyrant. If a provisional republic excludes from active membership some subgroup of its citizens, then it will have to demonstrate how excluded citizens can expect to gain full civil personality, and it will have to argue for provisionally enacted legislation in the interests of all rather than some subgroup of those citizens.

\section{Conclusion}

Kant's admittedly undemocratic distinction between active and passive citizenship demonstrates his awareness of the difficult problem of the gap between contractarian demands on citizen capacity and the reality of widespread citizen incapacity. Provisional contractarianism emphasizes the promotion of the possibility of a just political system (moving through conceivable if not actual consent, toward self-rule). Such a theory is deeply contractarian, but it is totally incompatible with the application of the exit-fromthe-state-of-nature test to existing citizens. From a Kantian point of view, applying the minimalist test rather than the test of government by consent makes little sense: the story of the escape from the state of nature merely illustrates the far more substantial principles at the heart of contract theory.

Kant's theory respects the voluntary ideal of contractarian citizenship, but not by unrealistically expecting domination-free interaction in the present world. Instead, a modern-day provisionalist contract theory would propose a series of context-sensitive, continually evolving institutional responses to the gap between the ideal and the practice of autonomous citizenship. Just as minimalist contractarians rely on public institutions like markets and banks to make good on their claims for the transhistorical value of private property, so Kantian contractarians would rely on public institutions to help them meet the substantive demands of citizenship $(6: 326 ; 6: 315)$. Freedom is at the heart of both strains of contract theory, but the Kantian strain recognizes that the state is not the only, or even the primary, source of domination in most citizens' lives. With such a Kantian revision of the traditional theory, Sugden's worries about "baseline" and "reciprocity" problems are resolved. Minimalist assumptions about property rights and citizen capacity may now be seen as context-dependent efforts to realize the provisional conditions of the contractarian ideal of government by consent.

\section{Acknowledgments}

For helpful suggestions and criticisms, I am grateful to Doug Dow, Steve Forde, Mika LaVaque-Manty, Brian Shaw, Ian Shapiro, and the anonymous review- 
ers; remaining errors are my own. Hassan Bashir provided invaluable research assistance. Parts of the argument as it developed were presented at meetings of the Lone Star Chapter of the Conference for the Study of Political Thought, the Association for Political Theory, the Western Political Science Association, and the American Political Science Association. I am grateful to the Office of the Vice President for Research, the College of Liberal Arts, and the Glasscock Center for Humanities Research at Texas A\&M University for support of research contributing to this article.

Manuscript submitted 10 August 2005

Manuscript accepted for publication 20 December 2005

\section{References}

Beiser, Frederick C. 1987. The Fate of Reason: German Philosophy from Kant to Fichte. Cambridge: Harvard University Press.

Beiser, Frederick C. 1992. Enlightenment, Revolution, Romanticism: The Genesis of Modern German Political Thought. Cambridge: Harvard University Press.

Braybrooke, David. 1987. "Social Contract Theory's Fanciest Flight.” Ethics 97 (July 1987): 750-64.

Buchanan, James, and Gordon Tullock. 1962. The Calculus of Consent: Logical Foundations of Constitutional Democracy. Ann Arbor: University of Michigan Press.

Burns, Nancy, Kay Lehman Schlozman, and Sidney Verba. 2001. The Private Roots of Public Action: Gender, Equality, and Political Participation. Cambridge: Harvard University Press.

Cavallar, Georg. 1999. Kant and the Theory and Practice of International Right. Cardiff: University of Wales Press.

Danilovic, Vesna, and Joe Clare. 2005. "Kant Revisited: Liberalism, Democracy, and Conflict." Typescript. Texas A\&M University.

Ellis, Elisabeth. 2005. Kant's Politics: Provisional Theory for an Uncertain World. New Haven and London: Yale University Press.

Flikschuh, Katrin. 2000. Kant and Modern Political Philosophy. Cambridge: Cambridge University Press.

Fraser, Nancy. 1994. "After the Family Wage: Gender Equity and the Welfare State." Political Theory 22 (4): 591-618.

Friedman, Thomas. 2005. “The Country We've Got." Editorial in the New York Times, 6 January, 27.

Gauthier, David. 1977. “The Social Contract as Ideology.” Philosophy and Public Affairs 6 (2): 130-64.

Gauthier, David. 1986. Morals By Agreement. Oxford: Clarendon Press.

Gauthier, David. 1993. "Between Hobbes and Rawls.” In Rationality, Justice and the Social Contract, eds. David Gauthier and Robert Sugden. Ann Arbor: The University of Michigan Press, 24-39.

Gutmann, Amy, and Dennis Thompson. 2004. Why Deliberative Democracy? Princeton: Princeton University Press.

Habermas, Jürgen. 1989. The Structural Transformation of the Public Sphere: An Inquiry into a Category of Bourgeois Society. Trans. Thomas Burger, with Frederick Lawrence. Cambridge: The MIT Press.
Hume, David. 1994. Political Essays. Ed. Knud Haakonssen. Cambridge: Cambridge University Press.

Huntington, Samuel. 1996. "Democracy for the Long Haul." The Journal of Democracy 7 (2): 3-13.

Kant, Immanuel. 1902. Kants gesammelte Schriften. Preussischen Akademie der Wissenschaften. Berlin and Leipzig: Walter de Gruyter \& Co.

Kant, Immanuel. 1996. Practical Philosophy. Ed. and trans. Mary J. Gregor. Cambridge: Cambridge University Press.

Katznelson, Ira, and Helen V. Milner, eds. 2002a. Political Science: The State of the Discipline. New York and London: W.W. Norton and Co.

Katznelson, Ira, and Helen V. Milner. 2002b. "American Political Science: The Discipline's State and the State of the Discipline." In Political Science: The State of the Discipline, eds. Ira Katznelson and Helen V. Milner. New York and London: W.W. Norton and Co., pp. 1-26.

Laursen, John Christian. 1986. “The Subversive Kant.” Political Theory 14 (4): 584-603.

Laursen, John Christian. 1992. The Politics of Skepticism in the Ancients, Montaigne, Hume, and Kant. Leiden and New York: E.J. Brill.

LaVaque-Manty, Mika. 2002. Arguments and Fists: Political Agency and Justification in Liberal Theory. New York and London: Routledge.

Levi, Margaret. 2002. “The State of the Study of the State.” In Political Science: The State of the Discipline, eds. Ira Katznelson and Helen V. Milner. New York and London: W.W. Norton and Co., pp. 33-55.

Locke, John. 2003. Two Treatises of Government and A Letter Concerning Toleration. Ed. Ian Shapiro. New Haven and London: Yale University Press.

Lyon, Bill. 2004. "Has it become too old-fashioned to remain civil?” Philadelphia Inquirer, November 23, 2004.

Marshall, T. H. 1964. Class, Citizenship, and Social Development: Essays. Garden City: Doubleday \& Co.

Mason, T. David. 1998. "Take Two Acres and Call Me in the Morning': Is Land Reform a Prescription for Peasant Unrest?” Journal of Politics 60 (1): 199-230.

Mill, John Stuart. 1989. On Liberty. Ed. Stefan Collini. Cambridge: Cambridge University Press.

Morris, Irwin L., and Joe A. Oppenheimer. 2004. "Rational Choice and Politics." In Politics from Anarchy to Democracy: Rational Choice in Political Science, eds. Irwin Morris, Joe Oppenheimer, and Karol Edward Soltan. Stanford: Stanford University Press, pp. 1-36.

Muthu, Sankar. 2000. "Justice and Foreigners: Kant's Cosmopolitan Right." Constellations 7 (1): 23-45.

Nozick, Robert. 1974. Anarchy, State and Utopia. New York: Basic Books.

Nussbaum, Martha. 2004. "Beyond the Social Contract: Capabilities and Global Justice." Oxford Development Studies 32 (1): 4-18.

Orloff, Ann Shola. 1993. "Gender and the Social Rights of Citizenship." American Sociological Review 58 (3): 303-28.

Pierson, Paul. 2004. Politics in Time: History, Institutions, and Social Analysis. Princeton: Princeton University Press.

Pogge, Thomas. 2002. “Is Kant's Rechtslehre a 'Comprehensive Liberalism'?” In Kant's Metaphysics of Morals, ed. Mark Timmons. Oxford: Oxford University Press, pp. 133-58.

Powell, Robert. 2002. "Game Theory, International Relations Theory, and the Hobbesian Stylization." In Political Science: 
The State of the Discipline, eds. Ira Katznelson and Helen V. Milner. New York and London: W.W. Norton and Co., pp. 755-83.

Przeworski, Adam. 1999. "Minimalist Conception of Democracy: A Defense.” In Democracy's Value, eds. Ian Shapiro and Casiano Hacker-Cordon. Cambridge: Cambridge University Press, pp. 23-55.

Putnam, Robert D. 2000. Bowling Alone: The Collapse and Revival of American Community. New York: Simon \& Schuster.

Rawls, John. 1971. A Theory of Justice. Cambridge: Harvard University Press.

Rawls, John. 2000. Lectures on the History of Moral Philosophy. Ed. Barbara Herman. Cambridge: Harvard University Press.

Riley, Patrick. 1982. Will and Political Legitimacy. Cambridge: Harvard University Press.

Rosen, Alan D. 1993. Kant's Theory of Justice. Ithaca: Cornell University Press.

Shapiro, Ian. 2003. The State of Democratic Theory. Princeton: Princeton University Press.

Shaw, Brian J. 2005. "Rawls, Kant's Doctrine of Right, and Global Distributive Justice." Journal of Politics 67 (1): 220-49.
Skocpol, Theda. 2003. Diminished Democracy: From Membership to Management in American Civic Life. Norman: University of Oklahoma Press.

Sugden, Robert. 1990. "Contractarianism and Norms.” Ethics 100 (July 1990): 768-86.

Sugden, Robert. 1993. “The Contractarian Enterprise.” In Rationality, Justice and the Social Contract, eds. David Gauthier and Robert Sugden. Ann Arbor: The University of Michigan Press, pp. 1-23.

Wolff, Robert Paul. 1998. "The Completion of Kant's Moral Theory in the Tenants of the Rechtslehre." In Autonomy and Community: Readings in Contemporary Kantian Social Philosophy, eds. Jane Kneller and Sidney Axinn. Albany: SUNY Press, pp. 39-61.

Elisabeth Ellis is assistant professor of political science, Texas A\&M University, College Station, TX 77843. 